\title{
Modified Delphi Survey on Key Attributes for Selection of Water-treatment Technologies for Horticulture Irrigation
}

\author{
Rosa E. Raudales ${ }^{1}$, Tracy A. Irani ${ }^{2}$, Charles R. Hall ${ }^{3}$, and \\ Paul R. Fisher ${ }^{4,5}$
}

AdDitional INDEX WORDs. adoption, disinfestation, innovation, recirculation, waterborne pathogens

Summary. A wide range of water-treatment technologies is used to control waterborne microbial problems in greenhouse and nursery irrigation. An online modified Delphi survey was carried out to identify the perceived key attributes that growers should consider when selecting among water-treatment technologies and to characterize a list of 14 technologies based on those same attributes. The expert panel consisted of ornamental plant growers $(n=43)$, water-treatment industry suppliers $(n=28)$, and research and extension faculty $(n=34)$. The survey was delivered to the expert panel in two rounds. Response rate was $59 \%$ and $60 \%$ for the first and second rounds, respectively. Growers identified control of plant disease, algae, and biofilm as primary reasons for adopting technologies, whereas mandatory regulation was not a major reason for adoption. All 23 attributes (related to cost, system size, control of microorganisms, chemistry, ease of use, and regulation) were perceived to be important when selecting between water-treatment technologies. Injectable sanitizing chemicals such as chlorination were considered to have low capital cost, unlike technologies that required installation of more complex equipment, such as heat treatment, hydrogen peroxide, ozone, reverse osmosis, or ultraviolet radiation. Filtration (excluding membrane filtration) was the only technology not perceived to be effective to control microorganisms. Filtration and copper were not considered effective to control human food-safety pathogens. Ozone was rated the highest as a technology that removes or oxidizes agrochemicals. Chemical water treatments, as opposed to physical water treatments, were perceived to be sensitive to water quality parameters and to have residual effect through the irrigation. Chlorine gas was perceived to be the only technology for which regulatory permission would be an obstacle. All technologies were perceived to be effective in water with low electrical conductivity (EC) or in solutions containing water-soluble fertilizers. This survey documents perceived attributes of watertreatment technologies, which are most useful where experimental data are not yet available. Research and outreach needs were highlighted by cases where perceived attributes differed from available experimental data or where there was a lack of consensus between experts.

C ommercial greenhouse and nurseries use high water volumes, reportedly averaging over 22,000 gal/acre per day (Camberato and Lopez, 2010), and compete with

We thank the USDA-ARS Floriculture and Nursery Research Initiative, and industry partners of the Floriculture Research Alliance at the University of Florida (floriculturealliance.org) and Water Education Alliance for Horticulture (watereducationalliance.org) for supporting this research.

${ }^{1}$ Department of Plant Science and Landscape Architecture, University of Connecticut, 1376 Storrs Road, Storrs, CT 06269

${ }^{2}$ Department of Agricultural Education and Communication, University of Florida, 305 Rolfs Hall, Gainesville, FL 32611

${ }^{3}$ Department of Horticultural Sciences, Texas A\& M University, 2133 TAMU, College Station, TX 77843

${ }^{4}$ Environmental Horticulture Department, University of Florida,1549 Fifield Hall, Gainesville, FL 32611

${ }^{5}$ Corresponding author. E-mail: pfisher@ufl.edu. other industries and drinking water for high quality sources. Irrigation water in greenhouse and nursery operations can be a source or dispersal mechanism for pathogens, algae, and biofilm, especially when recirculated and surface-water sources are used. A broad spectrum of plant pathogens, including oomycetes, fungi, bacteria, viruses, and nematodes, have been detected in water sources or distribution systems (Hong and Moorman, 2005). Algae and biofilm can also be problematic in greenhouse production by clogging emitters (Bucks et al., 1979; Dehghanisanij et al., 2005; Gilbert et al., 1981; Juanico et al., 1995), harboring plant pathogens (El-Hamalawi, 2007; Goldberg and Stanghellini, 1990; Hyder et al., 2009), and causing worker-safety issues such as slippery walkways.

Review articles on technical aspects of water treatment (Ehret et al., 2001; Fisher, 2013; Newman, 2004; Raviv and Lieth, 2007; Runia, 1995; Stewart-Wade, 2011; Van Os, 2010; Zhou and Smith, 2002) have shown there is incomplete information about the technologies and their interactions with chemical and physical characteristics of water. Considerable research has been undertaken by plant pathologists on the efficacy of water-treatment technologies for controlling waterborne pathogens (Raudales, 2013). However, investigation has focused largely on chlorination and control of oomycetes with less information available for other combinations of technologies and target organisms. There are limited data estimating phytotoxicity thresholds for chemical water disinfectants. However, the high levels of active ingredient required to control resistant pathogens suggest that in many cases the effective dose may cause phytotoxicity. Knowledge gaps remain about the compatibility of watertreatment technologies with the many biological, chemical, physical, social, and economic factors that characterize greenhouse and nursery operations. All these possible factors make it difficult for growers to select a technology that best fits their operation.

Horticulture growers are willing to adopt risk-management strategies to prevent disease spread in their operations (Breukers et al., 2012). However, risk and uncertainty about disease-management strategies affect decision making and represent a barrier 
to adoption (McRoberts et al., 2011). Horticulture growers identified uncertainties about efficacy and costs as some of the barriers for adoption of diseasemanagement strategies (Breukers et al., 2012). Growers of ornamental crops indicated that a major obstacle to implement sustainable practices was the perception that the practices were not compatible with current operation systems (Dennis et al., 2010). Uncertainties about adopting a practice or technology lessen with time as growers acquire of information by experience or knowledge (Breukers et al., 2012; Feder and Umali, 1993; Marra et al., 2003; McRoberts et al., 2011; Rogers, 2003). Rogers (2003) described the "hardware" aspects of innovations as the technology itself and "software" aspects of innovations as the information or knowledge about the performance of the technology. Some researchers have proposed that models on adoption of innovations in agriculture should consider interrelationships associated with the innovation, such as changing chemical applications and fertilization practices when adopting a new plant variety (Feder, 1982; Smale and Heisey, 1993). Adoption of innovations in agriculture therefore requires consideration of additional factors other than the technology itself. Such factors can include operation size, adaptability to current infrastructure, perceived technical benefits, ease of use, costs, financial benefits, external incentives, and public policy among others (Adesina and Zinnah, 1993; Feder and Umali, 1993; Loo et al., 2012; Mangiafico et al., 2008; Padel, 2002; Rogers, 2003; Sunding and Zilberman, 2001).

Plant-disease management is a human decision-making process that would benefit from interdisciplinary research that combines social and natural sciences (Gent et al., 2011; McRoberts et al., 2011). Interdisciplinary research by plant pathologists, horticulturists, chemists, engineers, environmentalists, economists, and social scientists would be required to make a thorough analysis of all the factors that characterize water-treatment technologies for use in greenhouses and nurseries. However, given budget constraints on experimental research to resolve existing knowledge gaps, it is appropriate to use nonexperimental, but systematic, research designs.
The Delphi method involves soliciting a group of experts on an individual basis using a series of questionnaires to reach consensus about a problem for which quantitative data are not available or experimental-research designs are not feasible (Brown and Helmer, 1964; Dalkey and Helmer, 1963; Murray, 1979). In other words, the Delphi method is a structured communication process used to predict outcomes based on consensus of a group of experts (Mitroff and Turoff, 2002). The Delphi survey method is based on the epistemology of inexact sciences which convey quasi-laws based on past knowledge, experience, and critical analysis of the experts for prediction of a problem (Helmer and Rescher, 1959). Quasi-laws cannot be derived from simplified observations and are instead inferred by the experience and views of the experts of complex situations (Aligica and Herritt, 2009; Helmer and Rescher, 1959). A major distinction between the Delphi survey and other types of survey is that the expert panel has the opportunity to anonymously reconsider their answers based on their reaction to the group responses (Helmer and Rescher, 1959; Mitroff and Turoff, 2002). Selection of the expert panel involves nonprobability sampling as random selection of the experts is not possible given the demand of specific knowledge and experience (Hasson et al., 2000). Alternatives to deal with researcher bias on selection of the expert panel are self-rating of expertise (Brown and Helmer, 1964), peer nomination of experts (Murray, 1979), and selection based on indicators such as publications, research programs, or public presentations (Helmer and Rescher, 1959). Dalkey and Helmer (1963) designed the method as an anonymous survey to stimulate independent thinking by each of the participants. The Delphi method is carried out under anonymous conditions to prevent influence from other members of the panel, uneasiness to express opinion, and "bandwagon effect" in which all agree because it is the opinion of the majority (Helmer and Rescher, 1959). There is no standard definition of consensus, and some external factors (such as budget or time frame of project) might influence how consensus is defined. Consensus among the experts is defined a priori by the researchers with the goal of matching consensus to the objective of the research question (Hasson et al., 2000; Mitroff and Turoff, 2002; Sackman, 1974). The original Delphi method started with open-ended questions that lead to a list of parameters to be evaluated (Brown and Helmer, 1964). However, diverse modifications to the Delphi method have been developed to ease the process and to target more specifically attitudinal data (Mitroff and Turoff, 2002).

Specific objectives of this research were 1) to identify the perceived key attributes of water-treatment technologies that should be considered by growers when selecting a technology for their operation and 2) to characterize 14 available water-treatment technologies in terms of these attributes. A modified Delphi survey method was used to evaluate these objectives. Results of this survey were intended as a first step to develop a framework of selection criteria for water-treatment technologies in irrigation for control of waterborne pathogens, algae, and biofilm.

\section{Materials and methods}

The expert panel consisted of 43 growers, 28 industry suppliers, and 34 research and extension faculty $(\mathrm{N}=$ 105 , divided into the three "expert types"). The "grower" group members consisted of ornamental plant growers known to have one or more water-treatment technologies in their operation and who were identified during cooperative extension watertreatment workshops hosted by the Water Education Alliance for Horticulture, which is a university/industry education consortium. The "industry" group consisted of suppliers and consultants from companies with products or services focused on the design, installation, and maintenance of water-treatment technologies. The "researcher" group represented scientists who had published articles, had known experience on water treatment, or both. The names of the individuals who participated and their association remained anonymous throughout the process.

A list of 23 "attributes" ( shown in Table 1) that were potentially important in technology selection was developed based on informal grower and industry feedback by surveying during cooperative extension 
Table 1. Perceptions of an expert panel solicited via a modified Delphi survey that each attribute listed is important when selecting between water-treatment technologies. The expert panel was composed of growers of ornamental crops, researchers, and water-treatment industry suppliers with direct experience in one or more water-treatment technologies for control of pathogens in irrigation. The mean rating is based on a Likert scale from 1 (strongly disagree) to 5 (strongly agree).

\begin{tabular}{|c|c|c|c|}
\hline \multirow{2}{*}{$\frac{\text { Attributes for selection of water-treatment technologies in irrigation }}{\text { z }}$} & \multirow{2}{*}{ n } & \multicolumn{2}{|c|}{ Mean (Likert scale $\mathbf{1 - 5}$ ) } \\
\hline & & 4.7 & $\mathrm{a}^{\mathrm{y}}$ \\
\hline Controls plant pathogens & 54 & 4.6 & $\mathrm{ab}$ \\
\hline Is suitable for large operations ( $>5$ acres or $>10,000$ gal per day) & 50 & 4.6 & $\mathrm{abc}$ \\
\hline Easy to monitor active ingredient and efficient operation & 53 & 4.6 & $\mathrm{abc}$ \\
\hline Low risk of environmental impacts if treated water runs off from property & 54 & 4.6 & $\mathrm{abc}$ \\
\hline Is safe for workers to use & 53 & 4.6 & $\mathrm{abc}$ \\
\hline Regulatory permission is unlikely to be an obstacle & 54 & 4.3 & abcd \\
\hline Requires minimal maintenance for calibration, cleaning, or replacing parts & 53 & 4.3 & abcd \\
\hline Is suitable for small operations ( $<2$ acres) or small volumes (such as mist systems) & 49 & 4.2 & abcde \\
\hline Is effective in solutions containing water-soluble fertilizers & 52 & 4.2 & abcde \\
\hline Has low operating cost per volume of irrigation water & 54 & 4.2 & bcde \\
\hline Has a residual effect through the entire irrigation system & 54 & 4.1 & bcde \\
\hline Has a long shelf life of materials ( $>3$ mo.) & 53 & 3.9 & def \\
\hline Controls human food-safety pathogens & 54 & 3.7 & efg \\
\hline Is effective with low EC water & 52 & 3.7 & efg \\
\hline Has a low initial capital cost & 54 & 3.4 & $\mathrm{fg}$ \\
\hline Is effective at high water $\mathrm{pH}$ & 52 & 3.4 & $\mathrm{fg}$ \\
\hline Removes or oxidizes pesticides or herbicides & 50 & 3.3 & $\mathrm{~g}$ \\
\hline
\end{tabular}

${ }^{\mathrm{z}} 1$ acre $=0.4047$ ha, $1 \mathrm{gal}=3.7854 \mathrm{~L}$.

${ }^{y}$ Means were compared using Tukey's honestly significant difference test at $P<0.05$.

workshops. Water-treatment technologies included calcium hypochlorite, chlorine dioxide, chlorine gas, copper ionization, copper sulfate, filtration (excluding membrane filtration), heat treatment and pasteurization, hydrogen peroxide, hypochlorous acid, ozone, reverse osmosis/membrane filtration, silver ionization, sodium hypochlorite, and ultraviolet radiation.

A draft survey was developed with online Qualtrics ${ }^{\circledR}$ software (Qualtrics Laboratories, Provo, UT). The survey was approved by the University of Florida Institutional Review Board 02 under the protocol no. 2010-U1178. In a pilot study, this version of the survey was sent for clarification and verification to a subset of the expert panel of eight people from the three expert types. The survey was amended with minor changes based on the feedback received.

Round 1. The revised survey was sent to expert panel members, who were contacted multiple times based on Dillman's-tailored design method (Dillman et al., 2009). The first contact was via e-mail 2 weeks before sending the survey informing them about their selection as part of the expert panel and the upcoming survey. The survey was first sent via e-mail on 7 Jan. 2011. Over a period of 4 months, four reminders were sent to the expert panel including one postcard and three e-mails. Round 1 of the survey was closed on 4 May 2011. A booklet was sent to the expert panel in appreciation for completing round 1 of the survey, with notification that round 2 was forthcoming.

Round 1 of the survey consisted of several sections. The demographics section requested information on their job title, organization, years of experience with water-treatment technologies, and an open-ended question on that experience. Growers only were also surveyed as to their reasons for adopting water-treatment technologies, the area of crop production, and which technologies were currently in use at their operation. For objective 1 , which aimed to identify important factors in technology selection, all expert types were asked to evaluate the importance of different attributes in the selection between water-treatment options. In this section, the expert panel rated their level of agreement (on a Likert scale from 1 = strongly disagree, $3=$ neither agree or disagree, to $5=$ strongly agree) that each of the 23 attributes listed was an important selection criterion. A third section asked the expert panel to self-rate their level of expertise for each of 14 technologies using a Likert scale from $1=$ no knowledge, 2 = beginner, $3=$ informed without direct experience, $4=$ informed with direct working experience, to $5=$ expert. A fourth section related to objective 2 , which was to identify the attributes of each technology. The Qualtrics ${ }^{\circledR}$ software dynamically presented questions only on technologies for which a participant had a self-rated expertise level of at least " 3 informed without direct experience." The technology was rated by the survey participant based on a level of agreement (with a Likert scale from $\mathrm{l}=$ strongly disagree to $5=$ strongly agree) that each of the attributes listed accurately described a specific technology. In round 1 , open questions were also provided to allow comments about each of the attributes and technologies.

Round 2. The survey was sent to the subgroup of the expert panel who 
answered the questionnaire in round 1. The round 2 questionnaire included only sections 3 and 4 described for round 1 , and in this round the average expert panel response for each attribute from round 1 ("the round 1 response") was also included. For any question where the participant agreed with the round 1 response, the participants were asked to leave this value unchanged. If a participant disagreed with any round 1 response, the participants were asked to indicate their own response on the Likert scale. Round 1 responses left unchanged were therefore assumed to indicate agreement by the participant.

Average rating and the percentage of agreement among experts were the two criteria used to determine the expert panel's perception of the attributes that characterize water-treatment technologies. An average rating $>3.0$ indicated that the expert panel perceived the attribute to characterize the technology and an average rating $\leq 3.0$ indicated that the attribute did not characterize the technology. Average rating of 3.0 has been used as point of acceptance or rejection by other researchers (Duffield, 1993). When fewer than $30 \%$ of respondents changed the rating between rounds, the average round 1 response was considered "consensus" of the expert panel, whereas changes by $30 \%$ or more of the respondents indicated "disagreement." This threshold was based on the consensus level of $70 \%$ that has been previously used by other researchers (Loughlin and Moore, 1979; McKenna, 1994; Slaughter et al., 1999; Van Steenkiste et al., 2002).

Analysis of variance (ANOVA) was used (PROC GLM) in SAS (version 9.2; SAS Institute, Cary, NC) to analyze main and interaction effects of "expert type" and "attribute," and the main effect of "years of experience" in objective 1 (importance of "attributes" in technology selection). For objective 2, to determine "attribute" values for each technology, ANOVA was run by "attribute" using PROC GLIMMIX (SAS version 9.2), with main and interaction effects of "expert type" and "technology," and the main effect of "years of experience." Tukey's honestly significant difference test was used to compare means in all analyses at the $P \leq 0.05$ level. Delphi surveys are typically analyzed with descriptive statistics
(Hasson et al., 2000). However, inferential statistics in survey analysis provides more insights into the relationships between responses and rounds in surveys, including Delphi surveys (Hasson et al., 2000; Shah and Kalaian, 2009). Therefore, inferential statistics was used to analyze the data of this survey. The F test was used because it has been shown to be robust to interval data assumptions from Likert scales (Breukers et al., 2012; Carifio and Perla, 2007), including Delphi surveys with sample sizes larger than 30 experts (Kalaian and Kasim, 2012; Shah and Kalaian, 2009).

\section{Results and discussion Demographics}

The response rate of the survey was $59 \%$ and $60 \%$ for rounds 1 and 2 , respectively. The sample population that responded to round 1 included 27 grower, 15 industry, and 21 researcher experts, compared with 15 grower, 9 industry, and 14 researcher experts in round 2 . The majority (54\%) of the expert panel self-rated as having more than 10 years of experience, with $26 \%$ or $20 \%$ self-rated as having 5 to 10 years, or less than 5 years of experience, respectively. Silver ionization was the only technology where only two of the three expert types were represented (industry and researcher, $\mathrm{n}=7$ individuals), with no grower in the survey group with experience. Growers identified "to prevent plant diseases" $(74 \%)$, "to control algae" (65\%), "to control biofilm or clogging of equipment" $(65 \%)$, and "as a response to plant loss" (35\%) as "important reasons to adopt a water-treatment system in your operation." No growers indicated "it is a mandatory regulation in my area" as a reason to adopt a watertreatment technology. The operation size of the growers who participated in the survey ranged from 2.5 to 125.0 acres of covered greenhouse, 2.5 to 50.0 acres of open field production area, and 2.5 to 150.0 acres of total production area. The areas of greenhouse and open area production in the grower group totaled 430.0 and 246.0 acres, respectively. The mean value for operation areas for greenhouse and open area were 20.5 and 17.6 acres, respectively. Growers indicated that the technologies currently used either alone or in combination with other technologies were copper $(\mathrm{n}=9)$, chlorine $(\mathrm{n}=4)$, activated peroxygen $(n=4)$, chlorine dioxide $(n=4)$, ozone $(n=2)$, reverse osmosis $(\mathrm{n}=2)$, and rapid sand filtration (1).

\section{Objective 1: Attributes for selection of water-treatment technologies}

Attributes. In choosing the attributes that should be considered when selecting water-treatment technologies, the perceived importance differed between attributes $(P<0.001)$ and there was an interaction between expert type and attribute $(P<0.001)$. There was no main effect of expert type $(P=0.244)$, although years of experience did affect response $(P=0.001)$ (Table 1).

All 23 attributes had an average rating above 3.0 , a value meaning "neither strongly agree or disagree" that an attribute was important in the selection of water-treatment technologies. An average rating of 3.0 was previously set as the threshold for consideration in round 2 , and all 23 attributes were therefore conserved (Table 1). The highest rating for the attribute "if residues are present, they are not toxic to plants" was not significantly different from 11 other attributes that included aspects related to efficacy against a range of target organisms, practical aspects of worker safety and operation, and regulatory considerations. Operating and capital costs were lower-ranked attributes. Two potential reasons to install water-treatment systems, "controls human food-safety pathogens" or "removes or oxidizes pesticides and herbicides," were ranked lower than controlling plant pathogens, algae, and biofilm.

EXPERT TYPES AND EXPERIENCE. The perceived importance of attributes associated with control of algae, biofilm, and human food-safety pathogens differed between expert types. However, all expert types strongly agreed that "controls plant pathogens" was an important attribute. Researcher group perception on the importance that a technology "controls algae" $[$ mean \pm SD $(3.75 \pm 0.48)]$ was lower than the opinion of grower $(4.93 \pm 0.72)$ and industry groups $(4.50 \pm 0.27)$. Industry's perception of the importance that a technology "controls biofilm" $(4.93 \pm 0.27)$ was higher than growers $(4.21 \pm 0.88)$ 
and researchers group $(3.86 \pm 0.66)$. Growers' perception on the importance that a technology "controls human food-safety pathogens" (3.21 \pm 0.93 ) was lower than the perception of industry $(3.92 \pm 0.92)$ or researchers $(3.94 \pm 0.57)$. Lower rating of biofilm control and control of human foodsafety pathogens by growers compared with other expert types presumably meant that growers perceived these problems to be of lower importance in their own production systems. The grower population was primarily producing ornamental rather than edible crops, and may therefore have been less sensitive to human food-safety pathogens than other expert types. Researchers had a lower opinion of the importance that a technology "has a residual effect through the entire irrigation system" $(3.75 \pm 0.68)$ compared with the growers' opinion $(4.38 \pm$ 0.56). Researchers' perceived importance that a technology is "effective at high water $\mathrm{pH}$ " $(3.71 \pm 0.61)$ was higher than the industry's opinion $(3.00 \pm 1.04)$.

The overall perceived importance of attributes was greater for experts who self-rated as having either more than 10 years of experience or less than 5 years of experience (4.19 for both groups), compared with the group who self-rated as having the intermediate 5 to 10 years of experience (4.00). Despite a statistical significant effect of years of experience, there may not be a practical significance in this difference.

\section{Objective 2: Comparison of attributes between technologies}

In the next survey section, the rating scale indicated how strongly participants perceived that a particular attribute characterized each individual technology. In the ANOVA that evaluated effects of "technology," "expert type," and "years of experience" on attribute ratings, there were differences between technologies $(P<$ 0.05 ) for all 23 attributes. For six attributes, ratings differed across technologies between expert types. Across technologies, industry considered that water treatment had a higher initial capital cost and was not as suitable for small operations or small volumes, compared with other expert types. Researchers had a higher perception that water-treatment technologies were able to control plant pathogens, biofilm, human food-safety pathogens, and removal of pesticides and herbicides compared with growers and industry. The highest rating for "Controls biofilm" and "Controls human food-safety pathogens was by researchers, followed by growers and industry. Silver ionization was removed from the analysis because of small sample size $(\mathrm{n}=7)$.

Cost. The water-treatment technologies calcium hypochlorite, chlorine dioxide, chlorine gas, copper sulfate, hydrogen peroxide, hypochlorous acid, and sodium hypochlorite were considered to have a perceived "low initial capital cost" based on an average rating above 3.0 (Table 2). All of these technologies require a fairly simple, low cost injection system to deliver the dosage (Parke and Fisher, 2012). Copper ionization, filtration, heat treatment, ozone, reverse osmosis, and ultraviolet radiation were not considered to have low initial capital cost, with average ratings below 3.0 . Copper ionization was the only technology where at least $30 \%$ of experts disagreed in ratings of initial capital cost between rounds 1 and 2 , indicating a lack of consensus on this attribute.

Calcium hypochlorite, chlorine dioxide, chlorine gas, copper ionization, copper sulfate, filtration, hypochlorous acid, and sodium hypochlorite had average ratings above 3.0 for "has low operating cost per volume of irrigation water" (Table 2 ), although more than $30 \%$ of experts disagreed on ratings of ozone and hydrogen peroxide between rounds 1 and 2. A preliminary cost analysis indicates that operation costs for the different technologies can range widely between $\leq \$ 0.25$ and $\geq \$ 1.00$ per 1000 gal of water treated (Fisher, 2013). Considering the large volumes of water used for irrigation, minor changes in operation costs could result in large annual costs. A cost comparison of ultraviolet radiation and chlorine dioxide for control of Phytophthora cinnamomi in nurseries in Australia indicated that the capital and operation costs of chlorine dioxide were higher than ultraviolet radiation when the daily water use ranged between 5000 and $100,000 \mathrm{~L}$ per day (Mebalds et al., 1996). However, the capital cost of chlorine dioxide did not change between 10,000 and 100,000 L of water per day, suggesting that chlorine dioxide may be more cost-effective for treating large volumes of water. No comprehensive studies that compare the cost of other water-treatment technologies for use in irrigation are available.

System sIZE. All treatments other than chlorine gas were considered to be "suitable for small operation sizes (under 2 acres) or low water volumes such as mist systems," with an average rating above 3.0 (Table 2). However, there was no consensus (more than $30 \%$ of experts disagreed between rounds 1 and 2 ) regarding the suitability of chlorine dioxide, chlorine gas, hypochlorous acid, ozone, reverse osmosis, and ultraviolet radiation for small operations. Heat treatment, copper sulfate, and hydrogen peroxide were not considered to be suitable for large operations (Table 2). More than $30 \%$ of the expert panel disagreed on the ratings for the suitability of chlorine dioxide, hydrogen peroxide, and ozone for large operations.

Among the technologies being used by the grower group at the time of the survey, the only technologies used in small operations $<2$ acres was chlorine dioxide in stabilized packets with single stock tanks (a 1.3-acre operation) and copper ionization was used in a 2.5-acre operation. Copper ionization was the water-treatment technology used in the widest range of operation sizes (2.5 to 100 acres), followed by chlorine dioxide generators ( 9 to 100 acres), and sodium hypochlorite (25 to 100 acres). Although only $13 \%$ of growers indicated they were using nonmembrane filtration, it is likely that screen or other filters were in use in all operations. Calcium hypochlorite and chlorine gas were used in individual operations of 23 and 10 acre, respectively. Hydrogen peroxide, ozone, and reverse osmosis were used in operation sizes ranging between 10 and 25 acres, 25 and 50 acres, and 6 and 16 acres, respectively.

Control of MiCroorganisms. Filtration (excluding membrane filtration) was rated $\leq 3.0$ for all the attributes related to control of microorganisms including plant pathogens, algae, biofilm, and human-safety pathogens (Table 2). All other technologies had mean ratings above 3.0 for controlling algae and plant pathogens. Both forms of copper and filtration had a mean rating $\leq 3.0$ for the control of human food-safety pathogens. 


\section{Research Reports}

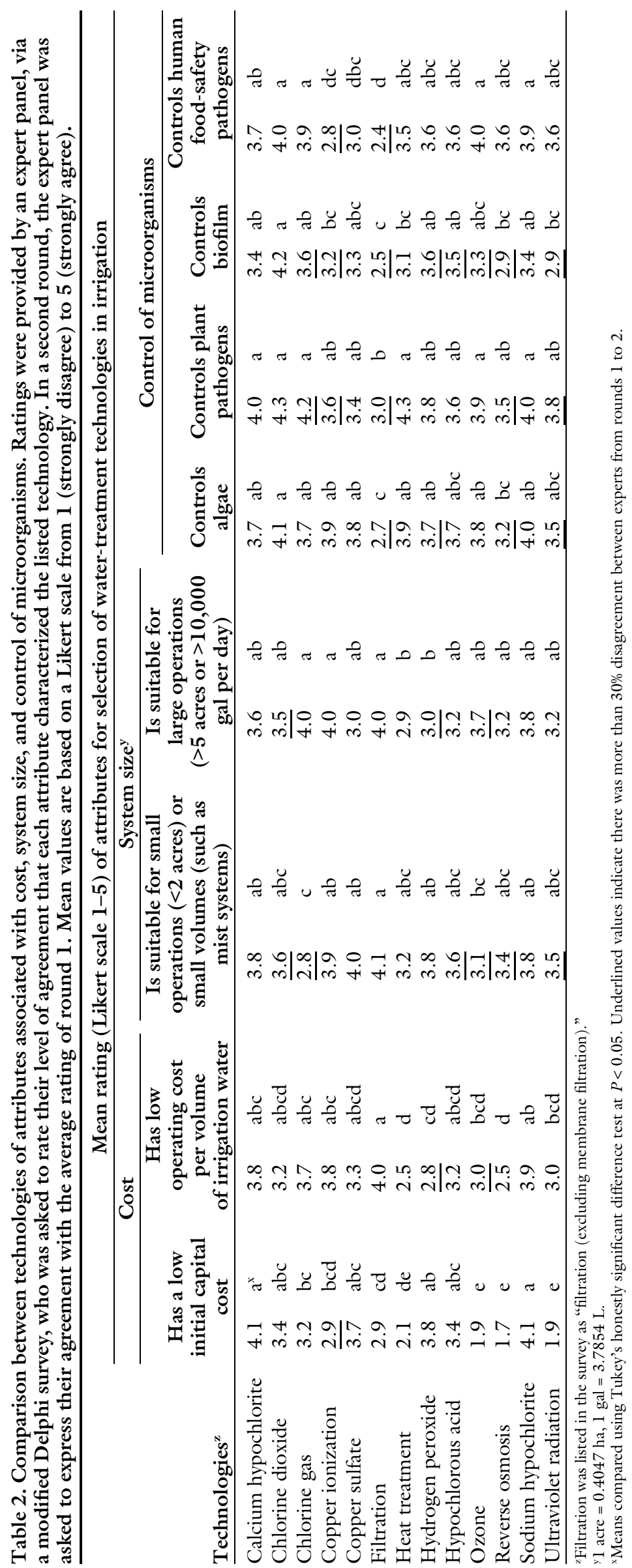


There was more than $30 \%$ disagreement among the expert panel on two or more attributes related to control of algae, plant pathogens, biofilm, or human food-safety organisms for the technologies chlorine gas, copper ionization, filtration, hydrogen peroxide, reverse osmosis, and ultraviolet radiation.

Membrane filtration with small pore size $(<10 \mu \mathrm{m})$ or slow media filtration are the only filtration options for removal of microorganisms from water (Ehret et al., 2001; StewartWade, 2011; Van Os, 2010). Multiple stages of membrane filtration were more efficient in removing plant parasitic nematodes than a single filtration stage in experimental research (Moens and Hendricks, 1992; Ohtani et al., 2000). Disagreement among the experts for ratings related to filtration (excluding membrane filtration) may have arisen because slow media filtration was not specifically included as a technology in the survey. In contrast to screen filters, slow media filters significantly decreased Fusarium oxysporum, pelargonium flower break virus, Phytophthora cinnamomi, Phytophthora cryptogea, Radopholus similis, and Xanthomonas campestris (Berkelmann et al., 1995; CalvoBado et al., 2003; Minuto et al., 2008; Wohanka, 1995; Wohanka et al, 1999; Van Os et al., 1999).

Copper ionization was rated 3.6 for the attribute "controls plant pathogens.” However, 46\% of experts disagreed between rounds with this rating, indicating a lack of consensus. A high level of disagreement may have arisen because copper ionization requires extended contact times $(\geq 1 \mathrm{~h})$ at a typical dose of 1 to $2 \mathrm{mg} \cdot \mathrm{L}^{-1}$ for effective control of plant pathogens. For example, Agrobacterium tumefaciens (Wohanka et al., 2009a), Clavibacter michiganensis (Wohanka and Fehres, 2007a), Erwinia carotovora (Wohanka et al., 2007), Ralstonia solanacearum (Wohanka and Fehres, 2007b), and Xanthomonas hortorum (Wohanka and Fehres 2006a) treated with $2 \mathrm{mg} \cdot \mathrm{L}^{-1}$ required $24,2,1,1$, and $4 \mathrm{~h}$, respectively, to achieve $90 \%$ mortality of pathogen propagules. In contrast, other combinations of lower doses or contact times were ineffective in controlling these pathogens, and certain pathogens (Fusarium oxysporum, Pythium aphanidermatum, and Trichoderma asperellum) were resistant to copper ionization treatment at $4 \mathrm{mg} \cdot \mathrm{L}^{-1}$ with contact times $\geq 1 \mathrm{~h}$ (Wohanka and Fehres, 2006b, 2006c; Wohanka et al., 2009b). Extended contact times are unlikely to occur in commercial greenhouse and nursery operations, unless treatment is applied in storage tanks with long residual time.

All technologies other than filtration, reverse osmosis, and ultraviolet radiation were considered to be effective at controlling biofilm. Because biofilm resides inside irrigation distribution lines, the point-treatment nature of the three aforementioned technologies, and therefore the lack of residual effect, reduces their potential efficacy in controlling biofilm. Biofilms are a matrix of polymers with a complex community of microorganisms attached to a surface (Costerton et al., 1995). The metabolic behavior and structure of biofilms is highly dependent on the microbial composition of the biofilm (Stoodley et al., 2002). In general, microbes attached to surfaces are more resistant to control than planktonic organisms (Bois et al., 1997; LeChevallier et al., 1988). Treatment with $0.5 \mathrm{mg} \cdot \mathrm{L}^{-1}$ chlorine reduced the density of coliform pathogens in the biofilm and resulted in release of biofilm particles, but it did not completely control biofilm (Morin et al., 1996).

All technologies except copper ionization and filtration were considered to be effective at controlling human food-safety pathogens (Table 2). Inactivation of human pathogens has been widely studied in drinking water (Maier et al., 2009). Irrigation water has been identified as a potential source of human food-safety pathogens (Alsanius et al., 2011; GortáresMoroyoqui et al., 2011; Ijabadeniyi et al., 2011; Lewis Ivey and Miller, 2013; Steele and Odumeru, 2004). Irrigation water treated with chlorine gas or chlorine dioxide (both at residual concentrations of $1 \mathrm{mg} \cdot \mathrm{L}^{-1}$ ) in combination with slow sand filtration were not effective in reducing coliform bacteria to the U.S. Environmental Protection Agency (USEPA) required levels (Lewis Ivey and Miller, 2013). Control and monitoring of food-safety pathogens in irrigation will be necessary given increasing regulation to reduce the risk of waterborne contamination of fresh produce by human pathogens (U.S. Food and
Drug Administration, 2013). More research is required to determine synergistic efficacy of control of plant pathogens and human pathogens.

EFFECT ON NUTRIENT OR INORGANIC MOLECULES. Calcium hypochlorite, copper ionization, copper sulfate, filtration, hypochlorous acid, and ultraviolet radiation were rated $\leq 3.0$ for the attribute "removes or oxidizes pesticides or herbicides" (Table 3). Ozone, which was given the highest rating (3.6) for this attribute, is commonly used to remove pesticides from natural water resources and drinking water supplies (Chiron et al., 2000). Ozone oxidizes directly or via hydroxyl free radicals, which is the strongest oxidizer form (Hoigné and Bader, 1976). Hydroxyl free radicals can result in complete mineralization of molecules (Chiron et al., 2000). Other technologies may be used alone or in combination with other technologies to reduce pesticide levels in irrigation water, including reverse osmosis, carbon filtration, chlorination (or other oxidizers), and ultraviolet radiation (Chian et al., 1975; Chiron et al., 2000; Kamel et al., 2009; Lafi and Al-Qodah, 2006; Legrini et al., 1993).

Calcium hypochlorite, copper sulfate, hydrogen peroxide, hypochlorous acids, ozone, reverse osmosis, and sodium hypochlorite were the only technologies with ratings $\leq 3$ for the attribute "fertilizers including micronutrients are not affected." Ozone can oxidize manganese, iron, and any other micronutrient chelates (OhashiKaneko et al., 2009; Vanachter et al., 1988). Reverse osmosis removes most nutrients from irrigation water (Runia, 1995). Calcium hypochlorite, hydrogen peroxide, hypochlorous acid, and sodium hypochlorite were also rated $\leq 3.0$, presumably because it is assumed that they are a strong enough oxidizers to affect organic chelates, although data are not available.

SENSITIVITY TO WATER QUALITY PARAMETERS. Several technologies including calcium hypochlorite, chlorine dioxide, chlorine gas, copper ionization, copper sulfate, hydrogen peroxide, hypochlorous acid, and sodium hypochlorite had ratings below 3.0 for the attribute "is effective at high water pH" (Table 3). More than 30\% of experts disagreed for ratings of calcium hypochlorite, chlorine gas, copper ionization, and sodium hypochlorite 


\section{Research Reports}

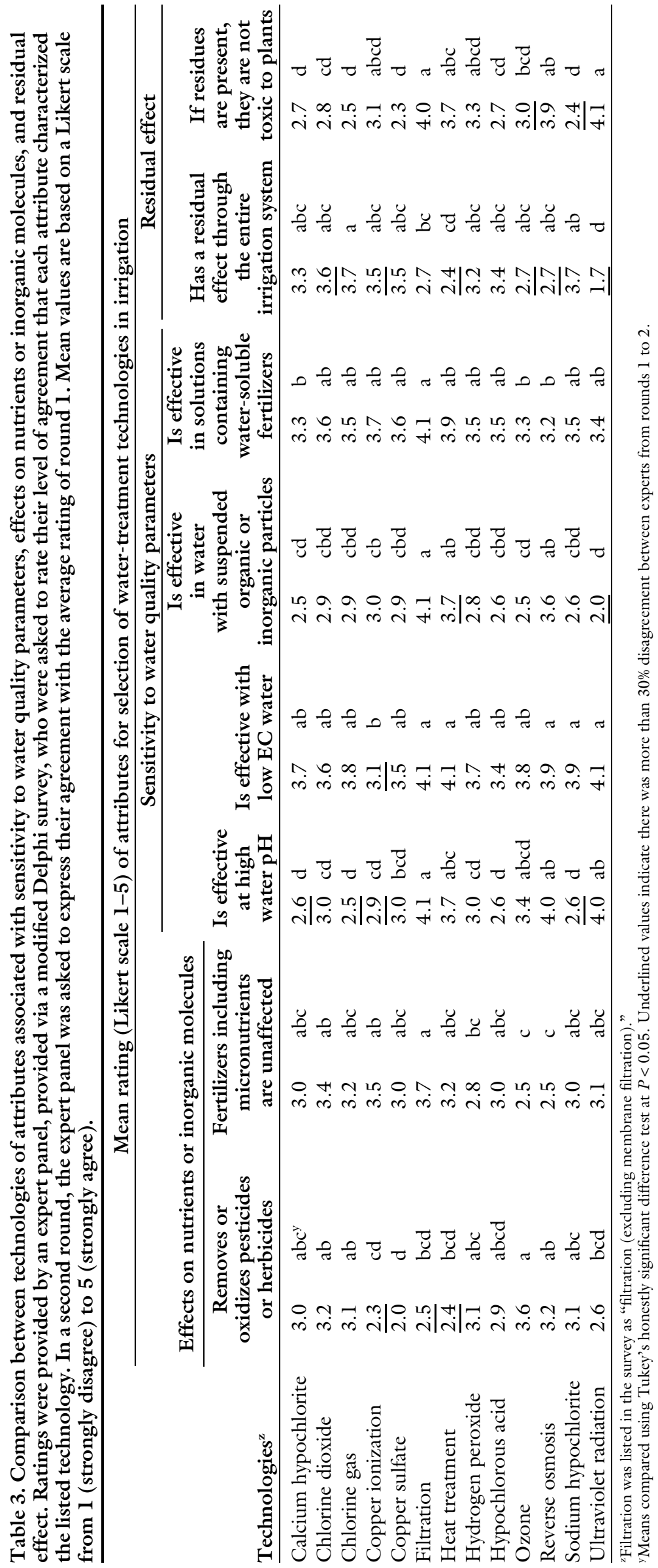


for this attribute. Hypochlorous acid, which is the active ingredient of calcium hypochlorite, chlorine gas, hypochlorous acid, and sodium hypochlorite, has decreased sanitizing activity as $\mathrm{pH}$ increases (Lang et al., 2008; White, 1992). Chlorine dioxide is effective at a wider $\mathrm{pH}$ range than other chlorine forms (Faust and Aly, 1983). Copper solubility also decreases with increasing pH (Lindsay, 1979), which could reduce efficacy of copper ionization and copper sulfate. All the technologies had ratings above 3.0 for "is effective with low EC water," although there was no consensus for copper ionization. Higher EC facilitates electrolysis in solutions, and therefore ionization of copper or silver (Fischer et al., 2008). Copper ionization units currently used in horticulture differ in their ability to adjust to the changing EC that commonly occurs in greenhouses using water-soluble fertilizers, and the authors have frequently measured doses of copper lower than the target concentrations in commercial greenhouse installations.

Filtration (excluding membrane filtration), heat treatment and reverse osmosis were the only technologies rated above 3.0 for the attribute "effective in water with suspended organic and inorganic particles" (Table 3 ). More than $30 \%$ of the experts disagreed about the average rating of heat treatment and ultraviolet radiation. Chemical sanitizers are affected by the presence of organic particles in the solution because the particles exert chemical sanitizer demand, therefore reducing the residual active ingredient. for sanitizing water (Fisher et al., 2013). It is well known that ultraviolet radiation efficacy is affected by the presence of organic and inorganic particles that block the transmission of radiation to the target organism (Yiaosumi et al., 2005). One of the principle roles of filtration in water treatment is to reduce suspended solids and sanitizing agent demand (Maier et al., 2009), and survey results reinforce the importance of filtration as an essential component of any water treatment system design. In addition, the rating and the disagreement for ultraviolet radiation indicates the need to educate growers on water clarity and pretreatment when using ultraviolet radiation for sanitation.

All the technologies were rated $\geq 3.2$ for the attribute "effective in solutions containing water-soluble fertilizers" (Table 3 ). However, in a study where chlorine interacted with ammonium, a reduction in oxidation reduction potential and free chlorine were observed (Meador and Fisher, 2013), which would be expected to occur because of conversion of hypochlorous acid (free chlorine) to chloramine (combined chlorine) (Deborde and von Gunten, 2008). It is unknown how chloramines affect the efficacy to control plant pathogens. Research on human health found chloramine was more effective than hypochlorous acid in reducing the incidence of Legionella and biofilm buildup (Lin et al., 2011); however, longer contact times are required (Degrémont, 1979).

RESIDUAL EFFECT. Filtration (excluding membrane filtration), heat treatment, ozone, reverse osmosis, and ultraviolet radiation were not considered to have the attribute "has a residual effect through the entire irrigation system" (Table 3). As discussed early in relation to biofilm control, most of these technologies are characterized as point treatments, in contrast with chemicals that are transported through the irrigation system (Stewart-Wade, 2011). Ozone is an unstable oxidant with fast reaction in water (Hoigné and Bader, 1994), which by definition reduces its residual activity.

Copper ionization, filtration (excluding membrane filtration), heat treatment, ozone, reverse osmosis, and ultraviolet radiation were perceived to have the attribute "if residues are present, they are not toxic to plants" (Table 3). However, more than $30 \%$ of the expert panel disagreed on the ratings for chlorine dioxide, copper ionization, heat treatment, ozone, reverse osmosis, sodium hypochlorite, and ultraviolet radiation for one of the attributes related to residual effect (Table 3 ). Chlorine applied at $2.4 \mathrm{mg} \cdot \mathrm{L}^{-1}$ (Cayanan et al., 2009), chlorine dioxide at $2.5 \mathrm{mg} \cdot \mathrm{L}^{-1}$ (Rens, 2011), ozone at $0.9 \mathrm{mg} \cdot \mathrm{L}^{-1}$ (Graham et al., 2009), and hydrogen peroxide at $8 \mathrm{mg} \cdot \mathrm{L}^{-1}$ (Vänninen and Koskula, 1998) have resulted in phytotoxicity of diverse crops.

EASE OF USE. Copper sulfate, hypochlorous acid, ozone, and ultraviolet radiation were not considered to have the attribute "easy to monitor active ingredient and efficient operation" (Table 4 ). More than $30 \%$ of the expert panel disagreed with the ratings on ease of monitoring for copper ionization, heat treatment, hydrogen peroxide, and ozone. Inline and handheld devices and kits are available for onsite monitoring active ingredients of sanitizing agents (Fisher, 2013). Chlorine gas and sodium hypochlorite were the only technologies perceived as not being "safe for workers to use" (Table 4). Chlorinebased products have been categorized in Toxicity Category I, which is the highest degree of acute toxicity established by the USEPA, 1999). Chlorine dioxide, chlorine gas, ozone, and reverse osmosis were not considered to have the attribute "simple to use and does not require specialist training for workers" (Table 4). Chlorine gas, ozone, reverse osmosis, and ultraviolet radiation were not considered to have the attribute "requires minimal maintenance for calibration, cleaning, or replacing parts" (Table 4 ). All technologies were rated $\geq 3.0$ for the attribute "has a long shelf life of materials (>3 months)" (Table 4).

Regulation. Chlorine gas was the only technology not considered to have the attribute "regulatory permission is unlikely to be an obstacle" (Table 4). More than $30 \%$ of the expert panel disagreed with the ratings for the attribute "regulatory permission is unlikely to be an obstacle" for the technologies chlorine dioxide and chlorine gas (Table 4). USEPA under the National Primary Drinking Water Regulations created a list of disinfectants and disinfection byproduct contaminants, specifying the maximum contaminant level (MCL) for various sanitizers and their byproducts for public water sources (Tarver, 2008; USEPA, 2013). The MCL for disinfectants are $0.8 \mathrm{mg} \cdot \mathrm{L}^{-1}$ for chlorine dioxide and $4 \mathrm{mg} \cdot \mathrm{L}^{-1}$ for chlorine as annual average (Tarver, 2008; USEPA, 2013). The MCL for disinfectant byproducts are $0.01 \mathrm{mg} \cdot \mathrm{L}^{-1}$ for bromate, $1.0 \mathrm{mg} \cdot \mathrm{L}^{-1}$ for chlorite, $0.06 \mathrm{mg} \cdot \mathrm{L}^{-1}$ for halo acetic acids (HAA5), and $0.10 \mathrm{mg} \cdot \mathrm{L}^{-1}$ for total trihalomethanes (Tarver, 2008; USEPA, 2013). Copper, which is listed under the inorganic chemicals contaminant, has an action level of $1.3 \mathrm{mg} \cdot \mathrm{L}^{-1}$ (USEPA, 2013). The action level "indicates the amount necessary to reduce the level of contaminant in drinking water" (Tarver, 2008). 


\section{Research Reports}

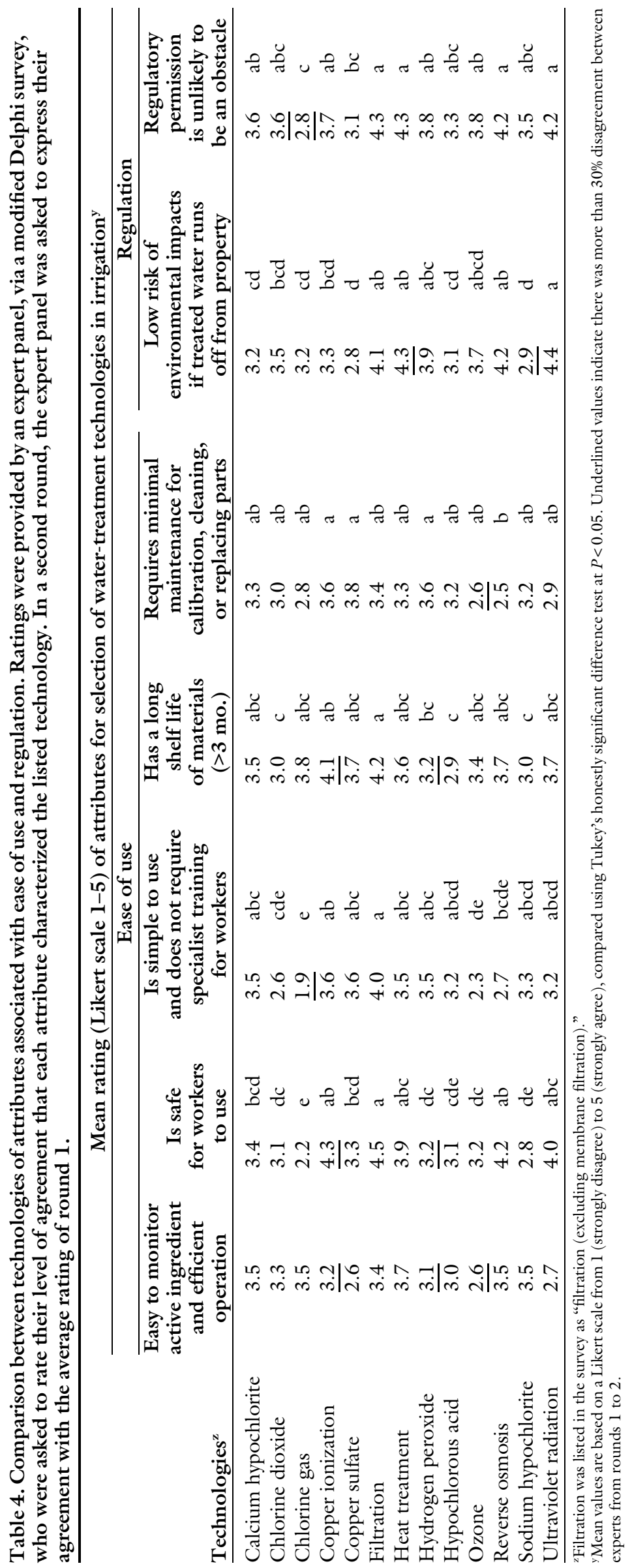




\section{Conclusions}

The results of this survey confirmed that decision making for selection of water-treatment technologies is multifaceted. Hence, multidisciplinary approaches are required to accurately model the selection process of water-treatment technologies in irrigation. Disagreement among experts, and lack of published quantitative research data, highlight areas of needed research and outreach. For example, the expert panel disagreed on 11 of 24 attributes that characterized copper ionization and in 8 of 14 technologies for the attribute "controls biofilm." The lack of consensus on attributes of copper ionization may result from limited research on this technology in the United States, given that most efficacy testing of copper ionization for control of plant pathogens has been carried out in Europe (Hopkins et al., 2009; Toppe and Thinggaard, 1998, 2000; Wohanka and Fehres, 2006a, 2006b, 2007a, 2007b; Wohanka et al., 2009a, 2009b). Technologies vary widely in the number of published efficacy studies (Raudales, 2013), with chlorine being the most studied technology. Aspects other than control of plant pathogens, such as control of biofilm or algae, or economic analysis of technology options, have received little attention despite the importance of these factors as identified by the survey panel.

More quantitative research on this topic will ensure that growers successfully meet future regulatory requirements to capture and recirculate water, and comply with food-safety regulations. Although the results of this survey do not substitute for quantitative experimental data, the information surveyed current perceived attributes of each technology. This analysis provided the necessary information for the development of a framework that will facilitate the decision-making process for growers by providing selection criteria of water-treatment technologies in irrigation for control of waterborne microbial problems. Growers and extension agents can identify the selection criteria that are priorities for the target operation and match these priorities with the strengths and weaknesses of each technology.

\section{Literature cited}

Adesina, A.A. and M.M. Zinnah. 1993. Technology characteristics, farmer's perceptions and adoption decisions: A Tobit model application in Sierra Leone. Agr. Econ. 9:297-311.

Aligica, P.D. and R. Herritt. 2009. Epistemology, social technology, and expert judgment: Olaf Helmer's contribution to futures research. Futures 41:253-259.

Alsanius, B.W., M. Alam, C. Larsson, A.K. Rosberg, S. Ahrné, G. Molin, and P. Jensén. 2011. Decontamination of irrigation water under field conditions: Preliminary results. Acta Hort. 922:6166.

Berkelmann, B., W. Wohanka, and G. Krezal. 1995. Transmission of pelargonium flower break virus (PFBV) by recirculating nutrient solutions with and without slow sand filtration. Acta Hort. 382: 256-262.

Bois, F.Y., T. Fahmny, J.C. Block, and D. Gatel. 1997. Dynamic modeling of bacteria in a pilot drinking water distribution system. Water Res. 31:3146-3156.

Breukers, A., M. van Asseldonk, J. Bremmer, and V. Beekman. 2012Understanding growers' decisions to manage invasive pathogens at the farm level. Phytopathology 102:609-619.

Brown, B. and O. Helmer. 1964. Improving the reliability of estimates obtained from a consensus of experts. RAND Rpt. P3925, RAND Corp., Santa Monica, CA.

Bucks, D.A., F.S. Nakayama, and R.G. Gilbert. 1979. Trickle irrigation water quality and preventive maintenance. Agr. Water Mgt. 2:149-162.

Calvo-Bado, L.A., T.R. Pettitt, N. Parsons, G.M. Petch, J.A.W. Morgan, and J.M. Whipps. 2003. Spatial and temporal analysis of the microbial community in slow sand filters used for treating horticultural irrigation water. Appl. Environ. Microbiol. 69:2116-2125.

Camberato, D.M. and R.G. Lopez. 2010. Commercial greenhouse and nursery production: Controlling algae in irrigation ponds. Purdue Ext. Publ. HO-247-W.

Carifio, J. and R.J. Perla. 2007. Ten common misunderstandings, misconceptions, persistent myths and urban legends about Likert scales and Likert response formats and their antidotes. J. Soc. Sci. 3:106-116.

Cayanan, D.F., M. Dixon, Y. Zheng, and J. Llewellyn. 2009. Response of containergrown nursery plants to chlorine used to disinfest irrigation water. HortScience 44:164-167.
Chian, E.S., W.N. Bruce, and H.H. Fang. 1975. Removal of pesticides by reverse osmosis. Environ. Sci. Technol. 9:52-59.

Chiron, S., A. Fernandez-Alba, A. Rodriguez, and E. Garcia-Calvo. 2000. Pesticide chemical oxidation: State-of-the-art. Water Res. 34:366-377.

Costerton, J.W., Z. Lewandowski, D.E. Caldwell, D.R. Korber, and H.M. LappinScott. 1995. Microbial biofilms. Annu. Rev. Microbiol. 49:711-745.

Dalkey, N. and O. Helmer. 1963. An experimental application of the Delphi method to the use of experts. Mgt. Sci. 9:458-467.

Deborde, M. and U. von Gunten. 2008. Reactions of chlorine with inorganic and organic compounds during water treatment-kinetics and mechanisms: A critical review. Water Res. 42:13-51.

Degrémont, S.A. 1979. Water treatment handbook. Halsted Press, New York, NY.

Dehghanisanij, H., T. Yamamoto, B. Ould Ahmad, H. Fujiyama, and K. Miyamoto. 2005. The effect of chlorine on emitter clogging induced by algae and protozoa and the performance of drip irrigation. Trans. Amer. Soc. Agr. Eng. 48:519527.

Dennis, J.H., R.G. Lopez, B.K. Behe, C.R. Hall, C. Yue, and B.L. Campbell. 2010. Sustainable production practices adopted by greenhouse and nursery plant growers. HortScience 45:12321237.

Dillman, D.A., J.D. Smyth, and L.M. Christian. 2009. Internet, mail and mixed-mode surveys: The tailored design method. 3rd ed. Wiley, Hoboken, NJ.

Duffield, C. 1993. The Delphi technique: A comparison of results obtained using two expert panels. Intl. J. Nurs. Stud. 30:227-237.

Ehret, D.L., B. Alsanius, W. Wohanka, J.G. Menzies, and R. Utkhede. 2001. Disinfestation of recirculating nutrient solutions in greenhouse horticulture. Agronomie 21:323-339.

El-Hamalawi, Z.A. 2007. Attraction, acquisition, retention and spatiotemporal distribution of soilborne plant pathogenic fungi by shore flies. Ann. Appl. Biol. 152:169-177.

Faust, S.D. and O.M. Aly. 1983. Chemistry of water treatments. Butterworth Publ., Woburn, MA.

Feder, G. 1982. Adoption of interrelated agricultural innovations: Complementarity and the impacts of risk, scale, and credit. Amer. J. Agr. Econ. 64:94-101. 
Feder, G. and D.L. Umali. 1993. The adoption of agricultural innovations: A review. Technol. Forecast. Soc. Change 43:215-239.

Fischer, R., P. Fisher, and A. Frances. 2008. Water treatment with copper ionization. GMPro 2008(Dec):18-21.

Fisher, P. (ed.). 2013. Water treatment: A growers guide for nursery and greenhouse irrigation. Water Education Alliance for Horticulture, Gainesville, FL.

Fisher, P., G. Mohammad-Pour, D.W. Haskell, J. Huang, and D. Meador. 2013. Water sanitizing agents such as chlorine and chlorine dioxide interact with peat substrate and suspended solids. Acta Hort. 1013:279-284.

Gent, D.H., E.D. De Wolf, and S.J. Pethybridge. 2011. Perceptions of risk, risk aversion, and barriers to adoption of decision support systems and integrated pest management: An introduction. Phytopathology 101:640-643.

Gilbert, R.G., F.S. Nakayama, D.A. Bucks, O.F. French, and K.C. Adamson. 1981. Trickle irrigation: Emitter clogging and other flow problems. Agr. Water Mgt. 3:159-178.

Goldberg, N.P. and M.E. Stanghellini. 1990. Ingestion-egestion and aerial transmission of Pythium aphanidermatum by shore flies (Ephydrinae: Scatella stagnalis). Phytopathology 80:777-779.

Gortáres-Moroyoqui, P., L. CastroEspinoza, J.E. Naranjo, M.M. Karpiscak, R.J. Freitas, and C.P. Gerba. 2011. Microbiological water quality in a large irrigation system: El Valle del Yaqui, Sonora México. J. Environ. Sci. Health Part A 46:1708-1712.

Graham, T., P. Zhang, Y. Zheng, and M.A. Dixon. 2009. Phytotoxicity of aqueous ozone on five container-grown nursery species. HortScience 44:774-780.

Hasson, F., S. Keeney, and H. McKenna. 2000. Research guidelines for the Delphi survey technique. J. Adv. Nurs. 32:10081015.

Helmer, O. and N. Rescher. 1959. On the epistemology of inexact sciences. Mgt. Sci. 6:25-52.

Hoigné, J. and H. Bader. 1976. The role of hydroxyl radical reactions in ozonation processes in aqueous solutions. Water Res. 10:377-386.

Hoigné, J. and H. Bader. 1994. Characterization of water quality criteria for ozonation processes. Part II: Lifetime of added ozone. Ozone Sci. Eng. 16:121-134.

Hong, C.X. and G.W. Moorman. 2005. Plant pathogens in irrigation water:
Challenges and opportunities. Crit. Rev. Plant Sci. 24:189-208.

Hopkins, D.L., C.M. Thompson, and B. Lovic. 2009. Management of transplant house spread of Acidovorax avenae subsp. citrulli on cucurbits with bactericidal chemicals in irrigation water. Plant Health Prog. Bul. 0129.

Hyder, N., M.D. Coffey, and M.E. Stanghellini. 2009. Viability of oomycete propagules following ingestion and excretion by fungus gnats, shore flies, and snails Plant Dis. 93:720-726.

Ijabadeniyi, O.A., L.K. Debusho, M. Vanderlinde, and E.M. Buys. 2011. Irrigation water as a potential pre-harvest source of bacterial contamination of vegetables. J. Food Saf. 31:452-461.

Juanico, M., Y. Azov, B. Teltsch, and G. Shelf. 1995. Effect of effluent addition to a freshwater reservoir on the filter clogging capacity of irrigation water. Water Res. 29:1695-1702.

Kalaian, S.E. and R.M. Kasim. 2012. Terminating sequential Delphi survey data collection. Pract. Assess., Res. Eval. 17(5):1-10.

Kamel, A., C. Byrne, C. Vigo, J. Ferrari, C. Stafford, G. Verdi, and J. Hedrick. 2009. Oxidation of selected organophosphate pesticides during chlorination of simulated drinking water. Water Res. 43:522-534.

Lafi, W.K. and Z. Al-Qodah. 2006. Combined advanced oxidation and biological treatment processes for the removal of pesticides from aqueous solutions. J. Hazard. Mater. 137:489-497.

Lang, J.M., B. Rebits, S.E. Newman, and N. Tisserat. 2008. Monitoring mortality of Pythium zoospores in chlorinated water using oxidation reduction potential. Plant Health Prog. Bul. 0922.

LeChevallier, M.W., C.D. Cawthon, and R.G. Lee. 1988. Inactivation of biofilm bacteria. Appl. Environ. Microbiol. 54:2492-2499.

Legrini, O., E. Oliveros, and A.M. Braun. 1993. Photochemical processes for water treatment. Chem. Rev. 93:671-698.

Lewis Ivey, M.L. and S.A. Miller. 2013. Assessing the efficacy of pre-harvest, chlorine-based sanitizers against human pathogen indicator microorganisms and Phytophthora capsici in non-recycled surface irrigation water. Water Res. 47: 4639-4651.

Lin, Y.E., J.E. Stout, and V.K. Yu. 2011. Controlling Legionella in hospital drinking water: An evidence-based review of disinfection methods. Infect. Control Hosp. Epidemiol. 32:166-173.
Lindsay, W.L. 1979. Chemical equilibria in soils. lst ed. Blackburn Press, Caldwell, NJ.

Loo, S.L., A.G. Fane, W.B. Krantz, and T.T. Lim. 2012. Emergency water supply: A review of potential technologies and selection criteria. Water Res. 46:31253151 .

Loughlin, K.G. and L.F. Moore. 1979. Using Delphi to achieve congruent objectives and activities in a pediatrics department. Acad. Med. 54:101-106.

Maier, R.M., I.L. Pepper, and P. Gerba. 2009. Environmental microbiology. 2nd ed. Elsevier Academic Press, Burlington, MA.

Mangiafico, S.S., J.P. Newman, M.J. Mochizuki, and D. Zurawski. 2008. Adoption of sustainable practices to protect and conserve water resources in container nurseries with greenhouse facilities. Acta Hort. 797:367-372.

Marra, M., D.J. Pannell, and A.A. Ghadim. 2003. The economics of risk, uncertainty and learning in the adoption of new agricultural technologies: Where are we on the learning curve? Agr. Syst. 75:215-234.

McKenna, H.P. 1994. The essential elements of a practitioners' nursing model: A survey of clinical psychiatric nurse managers. J. Adv. Nurs. 19:870-877.

McRoberts, N., C. Hall, L.V. Madden, and G. Hughes. 2011. Perceptions of disease risk: From social construction of subjective judgments to rational decision making. Phytopathology 101:654-665.

Meador, D.P. and P.R. Fisher. 2013. Ammonium in nutrient solutions decreases free chlorine concentration from sodium hypochlorite. HortScience 48:1304-1308.

Mebalds, M., A. van der Linden, M. Bankier, and D. Beardsell. 1996. Using ultraviolet radiation and chlorine dioxide to control fungal plant pathogens in water. Nurs. Pap. 5:1-2.

Minuto, A., L. Gaggero, M.L. Gullino, and A. Garibaldi. 2008. Influence of pH, nutrient solution disinfestation and antagonists application in a closed soilless system on severity of fusarium wilt of gerbera. Phytoparasitica 36:294-303

Mitroff, I.I. and M. Turoff. 2002. 11.B.Philosophical and methodological foundations of Delphi. In: The Delphi method: Techniques and applications. 30 Sept. 2012. <http://is.njit.edu/pubs/ delphibook/>.

Moens, M. and G. Hendricks. 1992. Drainwater filtration for the control of nematodes in hydroponic-type systems. Crop Protection 11:69-73. 
Morin, P., A. Camper, W. Jones, D. Gatel, and J.C. Goldman. 1996. Colonization and disinfection of biofilms hosting coliformcolonized carbon fines. Appl. Environ. Microbiol. 62:4428-4432.

Murray, T.J. 1979. Delphi methodologies: A review and critique. Urban Syst. 4:153-158.

Newman, S. 2004. Disinfecting irrigation water for disease management. Proc. 20th Annu. Conf. Pest Mgt. Ornamentals. Soc. Amer. Florists. p. 1-10.

Ohashi-Kaneko, K., M. Yoshii, T. Isobe, J.S. Park, K. Kurata, and K. Fujiwara. 2009. Nutrient solution prepared with ozonated water does not damage early growth of hydroponically grown tomatoes. Ozone Sci. Eng. 31:21-27.

Ohtani, T., A. Kaneko, N. Fukuda, S. Hagiwara, and S. Sase. 2000. Development of a membrane disinfection system for closed hydroponics in a greenhouse. J. Agr. Eng. Res. 77:227-232.

Padel, S. 2002. Conversion to organic farming: A typical example of diffusion of an innovation? Sociol. Ruralis 41:4061 .

Parke, J. and P. Fisher. 2012. Treating irrigation water to eliminate water molds, p. 5-49 In: J.W. Pscheidt and C.M. Ocamb (eds.). Pacific Northwest plant disease management handbook. 9 Apr. 2014. <http://pnwhandbooks.org/ plantdisease/pesticide-articles/treatingirrigation-water-eliminate-water-molds $>$.

Raudales, R. 2013. Characterization of water treatment technologies in irrigation. Univ. Florida, Gainesville, PhD Diss. UFE0046234.

Raviv, M. and J.H. Lieth (eds.). 2007. Soilless culture: Theory and practice. Elsevier, Burlington, MA.

Rens, L.R. 2011. Chlorine dioxide as sanitizing agent in recirculating irrigation for greenhouse hydroponic bell peppers. Univ. Florida, Gainesville, MS Thesis UFE0043811.

Rogers, E.M. 2003. Diffusion of innovations. 5th ed. Free Press, New York, NY.

Runia, W.T. 1995. A review of possibilities for disinfection of recirculation water from soilless cultures. Acta Hort. $382: 221-229$.

Sackman, H. 1974. Delphi assessment: Expert opinion, forecasting and group process. RAND Corp. Rpt. 1283, RAND Corp., Santa Monica, CA.

Shah, H.A. and S.A. Kalaian. 2009. Which is the best parametric statistical method for analyzing Delphi data? J. Mod. Appl. Stat. Methods 8:226-232.
Slaughter, A., R.V. Katz, and J.E. Grasso. 1999. Professional attitudes toward denture adhesives: A Delphi technique survey of academic prosthodontists. J. Prosthet. Dent. 82:80-89.

Smale, M. and P.W. Heisey. 1993. Simultaneous estimation of seed-fertilizer adoption decisions: An application to hybrid maize in Malawi. Technol. Forecast. Soc. Change 43:353-368.

Steele, M. and J. Odumeru. 2004. Irrigation water as source of foodborne pathogens on fruit and vegetables. J. Food Protection 67:2839-2849.

Stewart-Wade, S.M. 2011. Plant pathogens in recycled irrigation water in commercial plant nurseries and greenhouses: Their detection and management. Irr. Sci. 29:267-297.

Stoodley, P., K. Sauer, D.G. Davies, and J.W. Costerton. 2002. Biofilms as complex differentiated communities. Annu. Rev. Microbiol. 56:187-209.

Sunding, D. and D. Zilberman. 2001. Chapter 4: The agricultural innovation process: Research and technology adoption in a changing agricultural sector, p. 207-261. In: B.L. Gardner and G.C. Rausser (eds.). Handbook of agricultural economics. Vol. 1. Elsevier, Amsterdam, The Netherlands.

Tarver, T. 2008. "Just add water": Regulating and protecting the most common ingredient. J. Food Sci. 73:1-13.

Toppe, B. and K. Thinggaard. 1998. Prevention of Phytophthora root rot in gerbera by increasing copper ion concentration in the nutrient solution. Eur. J. Plant Pathol. 104:359-366.

Toppe, B. and K. Thinggaard. 2000. Influence of copper ion concentration and electrical conductivity of the nutrient solution on Phytophthora cinnamomi in ivy grown in ebb-and-flow systems. J. Phytopathol. 148:579-585.

U.S. Environmental Protection Agency. 1999. R.E.D. facts: Chlorine gas. EPA738-F-99-001. 19 Feb. 2014. <http:// www.epa.gov/oppsrrdl/reregistration/ REDs/factsheets/4022fact.pdf $>$.

U.S. Environmental Protection Agency. 2013. Drinking water contaminants. 19 Feb. 2014. <http://water.epa.gov/ drink/contaminants/index.cfm>.

U.S. Food and Drug Administration. 2013. Food Safety Modernization Act. 9 Apr. 2014. <http://www.fda.gov/ Food/GuidanceRegulation/FSMA/ default.htm>.

Van Os, E.A. 2010. Disease management in soilless culture systems. Acta Hort. 883:385-394.
Van Os, E.A., J.J. Amsing, A.J. van Kuik, and H. Willers. 1999. Slow sand filtration: a potential method for the elimination of pathogens and nematodes in recirculating nutrient solutions from glasshouse-grown crops. Acta Hort. 481: 519-526.

Van Steenkiste, B.C., J.E. Jacobs, N.M. Verheijen, J.H. Levelink, and B.J.A.M. Bottema. 2002. A Delphi technique as a method for selecting the content of an electronic patient record for asthma. Intl. J. Med. Inform. 65:7-16.

Vanachter, A., L. Thys, E. Van Wambeke, and C. Van Assche. 1988. Possible use of ozone for disinfestation of plant nutrient solutions. Acta Hort. 221:295-302.

Vänninen, I. and H. Koskula. 1998. Effect of hydrogen peroxide on algal growth, cucumber seedlings and the reproduction of shoreflies (Scatella stagnalis) in rockwool. Crop Protection 17:547-553.

White, G.C. 1992. Handbook of chlorination and alternative disinfectants, 3rd ed. Wiley/Van Nostrand, New York, NY.

Wohanka, W. 1995. Disinfection of recirculating nutrient solutions by slow sand filtration. Acta Hort. 382:246-255.

Wohanka, W. and H. Fehres. 2006a. Efficacy of water treatment with the Aquahort ${ }^{\circledR}$ - system against Xanthomonas hortorum pv. pelargonii. Geisenheim Res. Ctr., Rheingau, Germany

Wohanka, W. and H. Fehres. 2006b. Efficacy of water treatment with the Aquahort ${ }^{\circledR}$ - system against Fusarium oxysporum f.sp. cyclaminis. Geisenheim Res. Ctr., Rheingau, Germany.

Wohanka, W. and H. Fehres. 2006c. Efficacy of water treatment with the Aquahort ${ }^{\circledR}$ - system against Pythium aphanidermatum. Geisenheim Res. Ctr., Rheingau, Germany.

Wohanka, W. and H. Fehres. 2007a. Efficacy of water treatment with the Aquahort ${ }^{\circledR}$ - system against Clavibacter michiganensis ssp. michiganensis. Geisenheim Res. Ctr., Rheingau, Germany.

Wohanka, W. and H. Fehres. 2007b. Efficacy of water treatment with the Aquahort ${ }^{\circledR}$ - system against Ralstonia solanacearum Race 3. Geisenheim Res. Ctr., Rheingau, Germany.

Wohanka, W., D. Becker, and H. Fehres. 2009a. Efficacy of water treatment with the Aquahort ${ }^{\circledR}$ - system against Agrobacterium tumefaciens. Geisenheim Res. Ctr., Rheingau, Germany.

Wohanka, W., D. Becker, and H. Fehres. 2009 b. Efficacy of water treatment with the Aquahort ${ }^{\circledR}$ - system against Trichoderma 


\section{Research Reports}

asperellum. Geisenheim Res. Ctr., Rheingau, Germany.

Wohanka, W., H. Fehres, and W. Schoenbach. 2007. Efficacy of water treatment with the Aquahort ${ }^{\circledR}$ - system against Erwinia carotovora spp. carotovora. Geisenheim Res. Ctr., Rheingau, Germany.
Wohanka, W., H. Luedtke, H. Ahlers, and M. Luebke. 1999. Optimization of slow sand filtration as a means for disinfecting nutrient solutions. Acta Hort. 481:539544.

Yiaosumi, W., L. Evans, and L. Rogers. 2005. Farm water quality and treatment. Ag Facts AC 2 (April), 9th ed. Dept.
Primary Industries, Australia Government, Victoria, Australia.

Zhou, H. and D.W. Smith. 2002. Advanced technologies in water and wastewater treatment. J. Environ. Eng. Sci. 1:247-264. 